\title{
16: 64958064-64996190
}

National Cancer Institute

\section{Source}

National Cancer Institute. 16:64958064-64996190. NCI Thesaurus. Code C41928.

Physical location of CDH5_Gene 